Mariia Hupalo ${ }^{1}$

\title{
Motion of Human Nature towards Imago Dei in the Thought of St. Maximus the Confessor
}

The concept of becoming and flux has become central for postmodern philosophy. Anthropology in $21^{\text {st }}$ century needs to deal with the major questions that the ideological shifts and social disasters of the previous century have challenged us with, as well as new technocratic anthropologies that rise today. The well-known Judeo-Christian concept of image of God seems old-fashioned and irrelevant to modern highly technological society. Utilitarian philosophy presents us with a very pessimistic view on man: humans are hedonistic, egotistic and strive for personal interest. Society is a market of interests, where constant compromises and deals between conflicting needs occur. Another issue that returns to us in a new form is naturalism that becomes an organic part of techno-humanistic and transhumanistic worldview, dismisses human free will and ability to conform to ethical principles and reduces human decision-making to a highly complex, albeit not perfect algorithm ${ }^{2}$. Such views present dangerously mechanistic view of man that opens the possibility of objectification of human being.

1 Mariia Hupalo, STB, Lecturer and Junior Research Fellow at the Faculty of Philosophy and Theology of the Ukrainian Catholic University, Lviv, Ukraine; e-mail: mhupalo@ucu.edu.ua; ORCID: 0000-0002-9480-3191.

2 This view is expressed, for example, by a popular philosopher and historian Yuval Noah Harari throughout his works. See Y.N. Harari, Homo Deus: A Brief History of Tomorrow, New York 2016; Y.N. Harari, 21 Lessons for the 21st Century, New York 2018. 
Today, theology has to develop concepts that would prevent this objectification and help firmly establish the ontological basis for human dignity. To our opinion, the concept of imago Dei has an enormous potential that is still not fully exploited by theology. On one hand, many patristic theologians focus almost exclusively on historical reconstruction of Tradition, on the other, academic systematic theology often follows modern philosophical trends at costs of the genuine Christian tradition. One of these tendencies is to treat imago Dei as a strictly ethical or existential characteristic of man and not ontological. This position can have serious moral consequences. If the image of God lies in the sphere of becoming, it is not intrinsic to a human being and therefore it can only be acquired through moral endeavor. If the image of God does not belong to the substance of human being, there is a risk of dehumanization and disregard for human dignity. Therefore, we believe that the concept of imago Dei needs to be rediscovered and revisited in a manner that will be relevant to the new ideological challenges. These challenges include the healing of post-totalitarian societies as well as preventing the totalitarianisms of a new kind that emerge from abuse of technology.

Until recently, Maximian studies have focused almost exclusively on historical reconstruction of St. Maximus' doctrine. His Christology, cosmology, anthropology, ascetic doctrine, his refutation of Monothelitism/ Monenergism and Origenism have been thoroughly studied. There is, however, a new tendency in Maximian scholarship. The students of St. Maximus' thought brought to light the relevance of his theological and philosophical ideas for modern discourse, and recognition of Maximus as a European philosopher is growing ${ }^{3}$. John Zizioulas ${ }^{4}$ and Christos

3 See, for example, Maximus the Confessor as a European Philosopher, ed. S. Mitralexis et al., Eugene 2017; Knowing the Purpose of Creation through the Resurrection: Proceedings of the Symposium on St. Maximus the Confessor, ed. M. Vasilievic, Belgrade 2012.

4 J.D. Zizioulas, The Eucharistic Communion and the World, ed. L.B. Tallon, London 2011; The One and the Many: Studies on God, Man, the Church, and the World Today, ed. G. Edwards, Alhambra 2010; Being as Communion: Studies in Personhood 
Yannaras $^{5}$ are among the first thinkers that attempted an ambitious project of putting St. Maximus thought into dialogue with existentialism and philosophy of dialogue, especially Emmanuel Levinas. One might claim with a degree of certainty that John Zizioulas' eucharistic ecclesiology is a modern synthesis of Maximian thought. Nikolaos Loudovikos' Eucharistic Ontology ${ }^{6}$ is an attempt to correct some of the inconsistencies of Zizioulas' presentation of St. Maximus' anthropology, particularly his understanding of relations between logos, tropos, substance and person. Another valuable contribution to this branch of Maximian studies is Sotiris Mitralexis' monograph Ever-Moving Repose ${ }^{7}$. Other scholars that tried to put Maximus in dialogue with existentialist and phenomenological discourse include John Panteleimon Manoussakis ${ }^{8}$, Dionysios Skliris $^{9}$, Aristotle Papanikolaou ${ }^{10}$ and others. There are, however, several

and the Church, South Canan 1985; Communion and Otherness: Further Studies in Personhood and the Church, London 2006.

5 C. Yannaras, Person and Eros, Brookline 2007.

6 N. Loudovikos, A Eucharistic Ontology: Maximus the Confessor's Eschatological Ontology of Being as Dialogical Reciprocity, tr. E. Theokritoff, Brookline 2010.

7 S. Mitralexis, Ever-Moving Repose. A Contemporary Reading of Maximus the Confessor's Theory of Time, Eugene 2017.

8 J.P. Manoussakis, God after Metaphysics: A Theological Aesthetic, Indiana 2007; The Ethics of Time: A Phenomenology and Hermeneutics of Change, London 2016; Phenomenology and Eschatology: Not yet in the Now, London 2016.

9 D. Skliris, “Eschatological Teleology," "Free Dialectic," "Metaphysics of the Resurrection": The Three Antinomies That Make Maximus an Alternative European Philosopher, in: Maximus the Confessor as a European Philosopher, ed. S. Mitralexis et al., Eugene 2017, p. 3-23; Synodical Ontology: Maximus the Confessor's Proposition for Ontology, within History and in the Eschaton, in: Christian and Islamic Philosophies of Time, ed. S. Mitralexis - M. Podbielski, Delaware 2018, p. 89-122; St. Maximus the Confessor's Dialectic of Logos, Mode and End in a Postmodern Context: Its Importance to a Theological Evaluation of Race and Nationalism, "The Journal of Eastern Christian Studies" 69/1-4 (2017) p. 249-280.

10 A. Papanikolaou, Learning How to Love: Saint Maximus on Virtue, in: Knowing the Purpose of Creation through the Resurrection: Proceedings of the Symposium on St. Maximus the Confessor, ed. M. Vasilievic, Belgrade 2012, p. 239-250; Liberating Eros: Confession and Desire, "Journal of the Society of Christian Ethics" 26/1 (2006) p. 115-136; The Hermeneutical and Existential Contextuality of Orthodox Theologies of Personhood, "The Journal of Eastern Christian Studies" 69/1-4 (2017) p. 51-67; S.J. 
Maximian scholars that vehemently oppose such approach, Jean-Claude Larchet among the most well-known ${ }^{11}$. Demetrios Bathrellos ${ }^{12}$ and Georgi Kapriev ${ }^{13}$ warn that superimposing of existentialist connotations on Maximus' concept of hypostasis can distort our understanding of his anthropology. We shall touch this issue further on. However, we believe that, with some reservation, we can still use the existentialist and phenomenological dictionary and conceptual apparatus as a hermeneutic tool to St. Maximus thought.

Eucharistic ecclesiology, represented mainly by John Zizioulas, is treasured by Orthodox Churches and is gaining recognition in Ukrainian thological discourse. In Zizioulas' anthropology, the main accent is put on man's ability to relate to the Other, be it God or another human person or creation. Still, Zizioulas, much like Levinas ${ }^{14}$, sees relationality as a liberation from the tyranny of ontology ${ }^{15}$. On one hand, such a stance can be a medicine against ontological monism, but, on the other hand, puts hypostatic reality into an opposition to the essence of human being.

This study will examine the tension between the ontological fixedness of created beings and their motion towards communion with God. We shall attempt to show that theosis is not only the existential consummation of creaturely perfection, but also has its ontological basis in the logoi of created beings. We shall reflect on the epistemological and moral implications of St. Maximus' approach to cosmology and anthropology. This article will explore the relevance of his concept of motion in the

Salés, A. Papanikolaou, 'A power that deifies the human and humanizes God': the psychodynamics of love and hypostatic deification according to Maximos the Confessor, "International Journal of Philosophy and Theology" 78/1-2 (2017) p. 23-38.

11 J.-C. Larchet, Personne et nature: la Trinité, le Christ, l'homme: contributions aux dialogues interorthodoxe et interchrétien contemporains, Paris 2011.

12 D. Bathrellos, The Byzantine Christ: Person, Nature, and Will in the Christology of Saint Maximus the Confessor, Oxford 2004, p. 103-104.

13 G. Kapriev, Ipostas i energiia (Hypostasis and Energies), in: Sovremennaya bolgarskaya patrologia (Modern Bulgarian Patrology), Kyiv 2014, p. 113-136.

14 Levinas, Totalité et infini, p. 3.

15 Zizioulas, Communion and Otherness, p. 48. 
postmodern philosophical discourse and attempt at building bridges between Maximus the Confessor and philosophy of dialogue. This article will be a response and reflection on a study by Dutch theologian Katya Tolstaya Dehumanization as the key to a real understanding of the image of God, dedicated to the phenomenon of Muselmann/Dokhodyaga ${ }^{16}$ in the Nazi and Soviet concentration camps and the challenges that it presents for the understanding of imago Dei. To her opinion, the phenomenon of dehumanization of labor camp prisoners presents "a challenge [...] to post-traumatic philosophical and theological studies, as well as theological anthropology, in particular, the teaching about the image of God in man, since in theology, "the humane in human» (Varlam Shalamov) is traditionally associated with the image of God in man" ${ }^{17}$.

\section{The philosophical context}

Existentialist and postmodern philosophy reflects on the concept of mutability and becoming of beings. It is aware of the challenges that it presents for human mind in the search for philosophical certitude. While medieval and early modern thought was rather metaphysical and tried to find the source of absolute certainty in the idea of Being, the existential and postmodern philosophies focus mainly on becoming and relativity of human existence, and, therefore, on the tragedy of human state that fol-

16 Muselmänner and dokhodyagi (referring to the prisoners of Nazi concentration camps and Gulag labor camps respectively) was an informal term the political and/or war prisoners to designate the "walking dead", or people in a state of extreme physical, moral and psychological exhaustion, which was soon followed by death. For the representation of this phenomenon in the literature, see V. Shalamov, Kolyma Tales, tr. J. Glad, London 1995; P. Levi, If This Is a Man, tr. S. Woolf, Paris - London 2014.

17 K. Tolstaya, Raschelovechivanie kak kluch $k$ realnomu ponimaniyu obraza Bozhyego (Dehumanization as a Clue to the Realist Understanding of Imago Dei), "Vestnik Svyato-Filaretovskogo instituta (Review of Saint-Filaret Institute)" 12/2 (2019) p. 103 (referring to a draft version shared in private correspondence). 
lows from it. Albert Camus and Jean-Paul Sartre reflected on human life as a constant decision in the world that is stripped of sense and continuity. Emmanuel Levinas believed that the metaphysical concept of God is a threat to human freedom and authenticity, expressing the totalitarian strive to unification and monism. To his opinion, God is absent from this world, for man to become his prophet through kenotic relationship to the Other ${ }^{18}$. John Panteleimon Manoussakis, following Jean-Luc Marion's concept of saturated phenomenon, presents a methodology of "theology after metaphysics"19. This fundamental shift, however, reveals the polarity of being and becoming that can be found at the very origins of philosophical thought, for example, in the opposition between the Eleatic school and Heraclitus. Parmenides regarded Being as absolute, infinite, perfect and immutable; Heraclitus viewed mobility and becoming as primary to being. He claimed that being exists in perpetual flux and always moves between polarities. The latter are in constant opposition: they can achieve harmony by proper mutual balance, but they cannot be compromised. Platonism, which is usually thought of as mainstream Greek philosophy, followed the line of Parmenides, continuing his efforts to reconcile the absolute monism of Being and the multiplicity of beings. In its inculturation process, early Christianity and later Byzantine theology chose Platonism as its interlocutor, and therefore adopted its vocabulary. Sometimes, early Christianity is blamed for being influenced by the Platonic metaphysical discourse. Indeed, strong interactions with Middle Platonic and Neoplatonic philosophies resulted in major theological controversies, such as Arianism, Monophysitism, Origenism etc., but the attempts to reduce the immense variety of encounters between early Christianity and the culture(s) and belief(s) in late Roman Empire to the "corruption theory" is an oversimplification. Modern scholarship has long abandoned Adolph von Harnack's view that Christianity in its authentic form was the result of the "Hellenization"

\footnotetext{
18 E. Levinas, Totalité et infini, Nijhoff 1961, p. 37.

19 Manoussakis, God after Metaphysics, p. 19-28.
} 
of Jewish thought, and regard early Christianity as a phenomenon of its own $^{20}$. Although Medieval Christian thought is often accused for essentialism, the idea of creatio ex nihilo in fact marked the shift from Greek essentialism to a fundamentally new concept of relations between God and man. Christian trinitarian theology also introduced the concept of person into anthropology ${ }^{21}$. This new type of relations between God and creation could be called personal, or hypostatic, as it is the icon of intra-trinitarian communication and perichoresis.

When the essentialism of Western thought reached its consummation point, existentialist philosophy emerged. It can be thought of as a reaction to overly metaphysical and mechanistic thinking. Existentialist philosophers were convinced that the Rationalist tradition neglects the tragic situation of a real, living man in his everyday moral dilemmas. Therefore, Sartre's thought made a shift to radical becoming which, in its turn, led to moral relativism and uncertainty. Heidegger, however, tried to reconcile being and becoming. For him, becoming is being-as-it-seems: it is not actual non-being, because it in fact exists, but it still has not reached its final state, its perfection ${ }^{22}$. Being, becoming and thought at once exist and define the ontological state of an essence, although Heidegger differentiates Being per se and beings which possess $i^{23}$.

The tension between being and becoming is not only an epistemological or dialectical problem but has palpable consequences in anthropology and ethics. Ontological monism, as Eric Perl has noted ${ }^{24}$, is self-contradictory, as it immediately leads to dualism. Trying to find the universal principle of

20 P.L. Gavrilyuk, Harnack's hellenized Christianity or Florovsky's Sacred Hellenism: Questioning two metanarratives of early Christian engagement with late Antique culture, "St Vladimir's Theological Quarterly" 54/3-4 (2010) p. 323-344.

21 Zizioulas, Communion and Otherness, p. 113-177.

22 Cf. M. Heidegger, An Introduction to Metaphysics, tr. R. Manheim, New York 1961, p. 97.

23 Cf. Heidegger, An Introduction to Metaphysics, p. 170.

24 E.D. Perl, Methexis: Creation, incarnation, deification in Saint Maximus Confessor, Ph.D. dissertation, Yale University 1991, p. 16. 
being, it dismisses the multiplicity and diversity of beings which is irreconcilable with absolute simplicity. Monist anthropology leads to the dismissal of the concrete human being in his or her uniqueness and autonomy and provides an excuse for violations of the otherness for the sake of an "ideal society". This approach to anthropology led to the big social engineering projects that were followed by the catastrophes of Shoah, Holodomor, and other. The catastrophes that followed those projects led to the rejection of metanarratives and of ontology in general in fear of new totalitarian and monistic worldviews that neglect the concrete human being. Philosophy became much humbler about the abilities of human mind to achieve the absolute certainty and turned to apophaticism as an existential attitude, which can be regarded as a medicine against various kinds of exclusivism and objectification of truth and the world around us. However, postmodern worldview still needs an ontology, or otherwise it can fall into a trap it was so desperate to avoid. Without ontology, our search for truth is doomed to uncertainty and vagueness and vulnerable to arbitrary interpretations of morals. Paraphrasing Dostoyevsky, if there is no ontology, everything is permitted.

\section{Defining the imago Dei}

We shall start from definitions. How does Maximus the Confessor understand the concept of imago Dei? Is it identical to human nature, or does it lie in our personhood? Is it possible to lose or reclaim the image of God? Katya Tolstaya offered a classification of the various ways modern academic theology defines the image of God in relation to human being:

1. functional, which is based on Gen 1:26-27 and connects imago Dei with the role of man as a representative of God in creation and a steward of creation;

2. relational, which depends on the ability of man to relate to God and is external to his essence; 
3. dynamic, which is more properly called the likeness to God and requires moral endeavor and virtuous life and has eschatological connotations;

4. ontological, which regards the image of God as intrinsic to $\operatorname{man}^{25}$.

To her opinion, the experience of complete dehumanization presents such a scandal to conventional anthropology that no kind of ethical, hermeneutical or empirical understanding of imago Dei can grasp it or do the justice to the sufferings that led human beings to this state ${ }^{26}$. Although in modern Western academic theology the image of God is not regarded as an ontological quality of human nature, she insists that the ontological understanding of imago Dei is essential for proper understanding of the three other models, which otherwise would not make any sense.

To Tolstaya's opinion, the phenomenon of dehumanization should not be understood in ethical terms, because people who find themselves in such condition, are no longer able to take responsibility for their actions. Instead, we should treat this case in terms of ontology. This means that the image of God can potentially be lost "in essence"27. We would like to contest this opinion due to some problems that it creates in our understanding of human dignity. The vulnerability of human will indeed presents a challenge to anthropology, especially when we consider the atrocities that people committed against their fellows throughout history and continue to commit today or the way the miserable state of concentration camp prisoners induces them to lose their moral tonus completely. While we totally agree that imago Dei must be understood ontologically, we would rather restrain from saying that it can ontologically disappear completely. Indeed, phenomenologically and experientially, analyzing the extant testimonies, we might say that "the spark of God faded in them" 28 . But to assume that it disappears ontologically at a certain moment would be risky, since there are no criteria

25 Tolstaya, Raschelovecheniye, p. 126-128.

26 Tolstaya, Raschelovecheniye, p. 110-124.

27 Tolstaya, Raschelovecheniye, p. 129.

28 Levi, If This Is a Man, 114-115 (here and further referring to Ukrainian translation: Primo Levi, Chy tse lyudyna, tr. M. Prokopovych, Lviv 2017). 
to prove or refute this claim. This can lead to arbitrary assumptions and further dehumanization of a victim. This, in its turn, can be used to justify violations. Although this condition of despair and loss of personality is ontological, to our opinion, it lies in the realm of $\tilde{\varepsilon} \xi 1 \zeta$, or fixed condition, and not in the realm of essence. "E $\xi 1 \zeta$ is a state that is really present to human being and is not just a subjective experience, so we can safely mark it as an ontological state. Still, while $\check{\varepsilon} \xi 1 \varsigma$ can change, the core of human being, his or her identity as human person does not change. This is supported by Maximus' claim in Disputatio cum Pyrrho that virtue is inherent in human nature, and askesis is not meant to bring the virtue from outside, but to retrieve the virtue that has been obscured by the actions contrary to nature ${ }^{29}$. We might take this into an opposite direction: the extreme suffering and humiliation can obscure virtue and push it into the "underground" of human consciousness. When the suffering becomes less intense, there is again the possibility to recover natural human way of existence, which is testified by Primo Levi ${ }^{30}$.

In the following paragraphs we shall try to distinguish between the basic ontological concepts in Maximus' anthropology: logos, tropos, essence/substance/nature, hypostasis/person, energeia. We shall try to find out where exactly the image of God lies: in the nature or in the hypostasis. We shall also explore the concept of fixed-state ( $\left.\varepsilon_{\xi} \xi \varsigma\right)$.

Becoming is characterized in St. Maximus' theology by a scheme of two interconnected concepts: that of logos and tropos. Logos defines a creature's substance, its irreplaceable core and identity. Tropos, or mode of existence, is responsible for its existential state which it gains as a result of its becoming. Logos is an ontological principle which reflects the presence of creation in God's contemplation of Himself and the divine will to create beings $^{31}$. It is also the fundamental basis for creaturely participation in God

29 Maximus Confessor, Disputatio cum Pyrrho, Pospelov 2004, p. 178.

30 Levi, If This Is a Man, p. 222.

31 Maximus Confessor, Ambigua 7, tr. Nicholas Constas, Maximos the Confessor, On Difficulties in the Church Fathers: The Ambigua, Dumbarton Oaks 2014, v. 1, p. 109. 
which brings about beings' existence and perfection as this participation deepens. While God is Being in itself, creation does not exist as a source of itself, but by participation. Therefore, it is being only in a relative sense, to the extent of its participation in God's absolute being. As non-perfected and lacking, created entities strive to be realized in God and to more fully participate in Him and communicate with Him. Movement is a necessary feature of created being ${ }^{32}$, its internal faculty of self-determination ${ }^{33}$ and it is directed towards an end ${ }^{34}$. Maximus marks the connection between the logos of being and the image of God, because the presence of the image of God in a being reflects its likeness to Him as its Prototype ${ }^{35}$. The logos also reflects the eschatological state of human nature, towards which a man must direct his desire. The "eternal well-being", a state when a person is fully conformed to his/her logos, will be finally achieved through the divine grace. While the "well-being" as a moral state is achieved by human endeavor, the "eternal being" is a free gift of God. The image of God in man is present in his ontological core, the logos, according to which "every man is a particle of God, but not under any condition: he was created as a particle of God and remains as such as long as he moves according to his logos, otherwise he collapses and may return again to non-being" 36 . Therefore, the realization of the image of God in man is his existential and ethical duty, which also engages his free will, but does not depend solely on his endeavors and is not established and defined by man himself $f^{37}$. The man, his being and his destiny are given to him to realize them in time and space. Self-realization as autonomy and solipsism is rendered by the Confessor as an ill will which leads to non-being ${ }^{38}$. On the contrary, real

\footnotetext{
32 Maximus Confessor, Ambigua 7, tr. Constas, p. 81.

33 Cf. D. Bathrellos, Person, Nature, and Will in the Christology of Saint Maximus the Confessor, New York 2004, p. 134.

34 Maximus Confessor, Ambigua 7, tr. Constas, p. 83.

35 Maximus Confessor, Ambigua 7, tr. Constas, p. 91.

36 Maximus Confessor, Ambigua 7, tr. Constas, p. 101.

37 Maximus Confessor, Ambigua 65, tr. Constas, p. 279.

38 Maximus Confessor, Ambigua 65, tr. Constas, p. 281.
} 
freedom and real life are realized in communion with God and in a creative

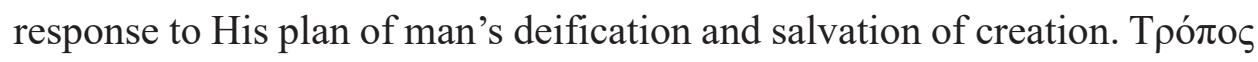
vंá $\rho \xi \varepsilon \omega \varsigma$, or mode of existence, reflects the way how a concrete person has consummated the divine plan manifested in the logos of his nature. The tropos is not identified completely with the concept of person ${ }^{39}$, although some theologians do identify hypostasis with tropos $^{40}$. Instead, it is a unique and individual way to fulfil one's own logos of nature, which is done by a particular hypostasis. Kapriev believes that logoi represent the ontological dimension of essence and hypostasis, while tropos reflects the existential realm.

Let us now briefly explore the concept of hypostasis as it is understood by Maximus, and the way hypostasis interacts with the world. First of all, we should distinguish between the basic ontological categories: substance, hypostasis and person (prosopon). The First and Second

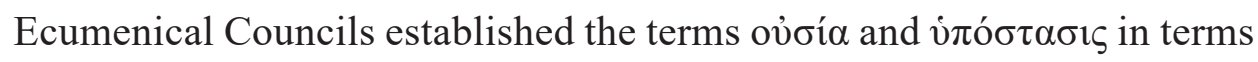
of triadology, which later influenced anthropology. In this framework, hypostasis designated individual beings, much like Aristotelian primary substance, and substance referred to more general categories, like genus and species, or Aristotelian secondary substance. Nature ( equivalent to substance, and person ( $\pi \rho$ ó $\sigma \omega \pi \mathrm{ov})$ corresponds to hypostasis. Essence designates what something is and what is the reason of its existence. Hypostasis, though, is a concrete individual representation of essence, a special way of existence ${ }^{41}$. In contrast to Western patristic model, which treats essence prior to person, for Maximus, hypostasis is what is directly given and is endowed with the highest degree of reality. Maximus insists that there is no nature which is not actualized in con-

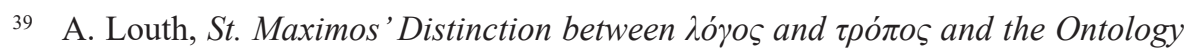
of the Person, in: Maximus the Confessor as a European Philosopher, ed. S. Mitralexis et al., Eugene 2017, p. 161.

40 See, for instance, Zizioulas, Communion and Otherness, p. 165; Mitralexis, EverMoving Repose, p. 30.

41 See Maximus Confessor, Opuscula theologica et polemica 14, PG 91, $152 \mathrm{~A}$. 


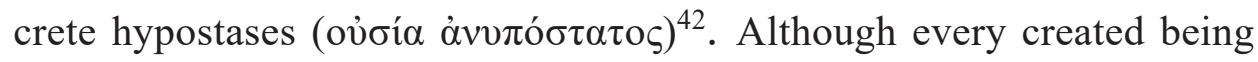
is a hypostasis of some kind, only human is endowed with an ability to be a person $\left(\pi \rho \sigma^{\sigma} \sigma \pi \mathrm{ov}\right)$ and to exist-in-relation. Personhood is both an integral characteristic of human being and a material to work with. A man can become more prosopic and communicate with others without division and confusion. To be a person is to conform to the trinitarian model of communion in all our relations and to participate in the tropos of existence of Christ the Logos ${ }^{43}$.

Georgi Kapriev criticizes some of the modern interpreters of Maximus who put essence and hypostasis into an opposition to each other. To his opinion, the existentialist reading of Maximus distorts his anthropology. Although Maximus, as a Christian thinker, indeed opposed Greek essentialism, he never dismissed essence as an ontological basis for human person. The priority of the person, which is so much upheld by John Zizioulas, does not mean that it can exist against or in spite of its essence. In the Opusculum 14, Maximus insists that every hypostasis is rooted in

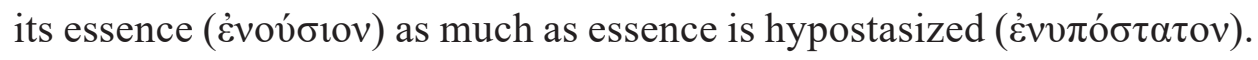
The nature is actually present ( $\pi \rho \alpha \gamma \mu \alpha \tau$ $1 \tilde{\omega} \varsigma)$ in the hypostasis and it is not just a set of features that it shares with other hypostases ${ }^{44}$. Also, it is not a logical abstraction, as the representatives of the nominalistic approach would claim. Therefore, the primacy of hypostasis must be understood soteriologically rather that ontologically ${ }^{45}$.

Cappadocian Fathers defined hypostasis as the presence of the common in the individual who has also his own unique characteristics ${ }^{46}$. Leontius of Byzantium developed this concept and defined it as "being-on-its-own" ( 42 See Maximus Confessor, Opuscula theologica et polemica 14, PG 91, 149B.
43 Loudovikos, A Eucharistic Ontology, p. 152.
44 See Maximus Confessor, Opuscula theologica et polemica 14, PG 91, 153A.
45 G. Kapriev, The Conceptual Apparatus of Maximus the Confessor and
Contemporary Anthropology, in: Maximus the Confessor as a European Philosopher, ed. S. Mitralexis et al., Eugene 2017, p. 169.

46 Cf. Basilius Magnus, Epistula 38, 2-3, PG 32, 325B-328C. 


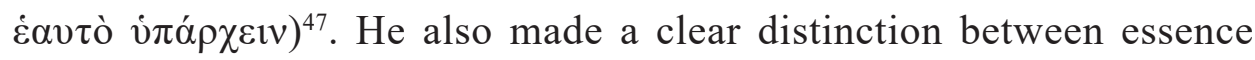

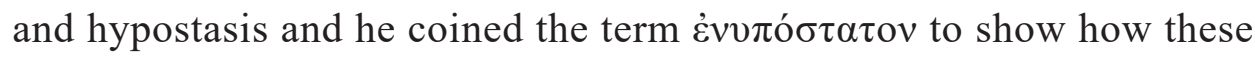
realities are interrelated. Maximus claims that hypostasis is separated from its substance matter (i.e. nature) and differs from $i t^{48}$. The hypostasis differs among other hypostases not only by number, but also by its unique characteristics and the way it reflects its substance ${ }^{49}$. Although different, nature and hypostases are mutually immanent, which leads to the existential realization of nature (i.e. theosis) and the ability of the hypostasis to actualize the natural energy ${ }^{50}$. To Kapriev's opinion, human relationality, his or her ability to represent himself and consciously use his natural faculties ( $\dot{\varepsilon} v \varepsilon \rho \gamma \varepsilon i ́ \alpha)$, lies in the realm of prosopon (person). At the same time, it cannot be reduced to bare relation ( $\sigma \chi \varepsilon \dot{\sigma} \sigma \varsigma)$ because to transcend himself, the subject must exist in the first place. Relationality is an essential characteristic of personhood, but not its ontological basis ${ }^{51}$.

Maximus the Confessor, through his understanding of the onticity of human person, presents a balanced position between ontology, relationality, and dynamism of human nature. According to St. Maximus the Confessor, the image of God is the reality that both belongs to the core of human nature and constitutes a dynamic dimension that reflects human likeness to God. The image of God is both something that belongs to us and a goal towards which human beings strive. To exist, every being must be at the same time identical to God (because only God, strictly speaking, is), and radically other (because there would be no creation without otherness) ${ }^{52}$. The nature, which is defined by

\footnotetext{
47 Leontius Byzantinus, Contra Nestorianos et Eutychianos 1, PG 86a, 1280A.

48 See Maximus Confessor, Opuscula theologica et polemica 14, PG 91, 152A.

49 See Maximus Confessor, Opuscula theologica et polemica 26, PG 91, 276AB.

50 Kapriev, The Conceptual Apparatus, p. 175.

51 Kapriev, The Conceptual Apparatus, p. 178-179.

52 Perl has noted how difficult it was for Neoplatonic thought and its antecedents to accept this antinomy. The concept of participation was coined by Plato and developed by Middle- and Neoplatonists to bridge the gap between Being and multiplicity. In most
} 
the logos, is the place of indwelling of the image of God. As well as the image of God, human nature is dynamic: change that a person goes through is not only a change of some attributes or a purely subjective experience but permeates the whole of $\operatorname{man}^{53}$. As P. Chrestou notes, while the image of God lies in man's being and eternal being, that is, his essence and deified state, likeness to God bears distinctive marks of a person that conforms to the image ${ }^{54}$. Being and eternal being belongs to the essence, but well-being, or moral life, reflected in goodness and wisdom, are offered to the gnomic capacity.

Created nature is not a goal in itself, its end lies outside of it, and the nature has to transcend itself to achieve its most true mode of existence. The existence "above nature" is overcoming a creaturely way of existence which is susceptible to corruption and disorder, although in overcoming this vulnerability the creation nevertheless does not become literally God or dissolve in the uncreated. Therefore, the image and likeness of God are not built over some "pure nature", as a "pure nature" without God doesn't exist. It is inherent in nature, endowing it with a desire (ő $\rho \varepsilon \xi 1 \varsigma$, है $\rho \omega \varsigma)$ of communion with the uncreated. Since the nature itself is understood by Maximus as relational, contrary to John Zizioulas' assumptions, it does not need to be overcome. Also, it cannot be equated to Levinas' concept of totality.

\footnotetext{
cases, however, these endeavors ended up with either denial of otherness or production of series of intermediary entities. Pseudo-Dionysius was a first Christian Neoplatonist to fully embrace simultaneous immanence and transcendence of God to the world and incorporate it into his worldview. Cf. Perl, Methexis, p. 73.

53 See Maximus Confessor, Ambigua 10.

54 Chrestou, Maximus the Confessor on the Infinity of Man, in: Maximus Confessor: Actes du Sumposium sur Maxime le Confesseur, Fribourg, 2-5 septembre, 1980, ed. F. Heinzer - C. von Schoenborn, Fribourg 1982, p. 263.
} 


\section{Movement as will and desire}

The concept of desire is indispensable from Maximus' understanding of natural movement. The idea that creatures participate in God as the Good and the Beautiful and strive to fuller and fuller communion with Him can be traced to as far as Plato ${ }^{55}$. Plotinus developed the picture of relation between the One and the world: the world originates from the outflowing ( $\pi \rho \circ o$ ó $\varsigma$ ) of divine creative power. The further it flows, the more diverse it is and the less it resembles the One, so it naturally longs to return to the original completeness. The process of reversion ( $\dot{\pi} \imath \sigma \tau \rho \circ \varphi \eta ́)$ is fueled by this desire ("̌ $\rho \omega \varsigma)$. The One, on its part, does not need anything as it is perfect and self-sufficient. In its very essence, the One is absolutely transcendent, closed, simple and opaque. It simply is, and an assumption that it could ever desire something other than itself would be a claim for its deficiency. Therefore, eros is one-sided, asymmetrical. The energy that emanates from the One is a necessary process due to its superabundant life, rather than a gift or an act of love towards beings. On the other hand, the platonic understanding of eros as a strive to fill the void or compensate the lack should not be properly called love. The love as it is described in Plato's Symposium is a pursuit of individual needs and desires rather than self-overcoming ${ }^{56}$. Plotinus' concept of eros is ecstatic, and at a first glance it might resemble Christian mystical experience, but in fact, it is an introspective and intellectualist spirituality that does not recognize any Otherness. The goal of Plotinian ecstasis is to realize that I am the One ${ }^{57}$. This approach is quite different from the kenotic idea of love in Christianity and spe-

55 See, for instance, Plato, Symposium 211b7-d1.

56 See Plato, Symposium 201b.

57 Of course, this presentation of Platonic and Plotinian eros is very simplified, since the scope of this article does not allow for a comprehensive presentation of this topic. For in-depth discussion on love in Plato and Plotinus, see A. Bertozzi, On Eros in Plotinus: Attempt at a Systematic Reconstruction (with a Preliminary Chapter on Plato), PhD dissertation, Loyola University 2012. 
cifically Maximus ${ }^{58}$. Although Maximus appropriates the Neoplatonic language of procession and return, his understanding of desire and love is strongly personalistic ${ }^{59}$.

Pseudo-Dionysius the Areopagite made a major shift in the philosophical definition of eros, which affected St. Maximus powerfully. This author is regarded by many ${ }^{60}$ as one of the most neoplatonizing Church Fathers. Nevertheless, in contrast to Neoplatonic philosophy, Dionysius understands God-world and God-man relations as a dialogue and exchange of gifts. He indeed expresses himself in strictly philosophical language, but the difference in approach is immense. What was seen in Neoplatonism as a natural process inside of deity, Dionysius presents as a conscious act of $\mathrm{God}^{61}$, and thus constitutes an important transition point to Maximus. According to Dionysius, God is immovable by nature, but moves through producing gravity of creatures toward Himself and towards other creatures, thereby creating reciprocity between them ${ }^{62}$. This gravity is possible because of the presence of divine logoi in creation. Unchangeability and self-sufficiency of God does not hinder Him from free loving conversation with his creation. Unlike in Neoplatonism, God is ek-statical, He is not only an ultimate object of love, but also Himself is infinite love and desire ${ }^{63}$. He estab-

58 See Maximus Confessor, De caritate 1, 1; 1, 12-13; 1, 15-19; 1, 23-28.

59 By personalism, we mean here not the particular philosophical school, but, more broadly, a discourse which puts person in its center.

60 Among the most prominent critics of Dionysius' "Neoplatonism" was John Meyendorff (Christ in eastern Christian thought, South Canan 1975, p. 101-123). This view was challenged by in A. Louth, The Reception of Dionysius in the Byzantine World: Maximus to Palamas, "Modern Theology" 24/4 (2008) p. 585-599. Loudovikos (A Eucharistic Ontology, p. 188) also disagrees with the idea that Dionysian supposed Neoplatonism was corrected by Maximus. To his opinion, on contrary, Maximus embraces Dionysian concept of self-transcending God and transfers it to his own anthropology. However, many of the modern Dionysian scholars still attribute a Neoplatonic worldview to him, Eric Perl among them, see E.D. Perl, Theophany: The Neoplatonic Philosophy of Dionysius the Areopagite, New York 2007.

61 See Dionysius Areopagita, De Divinis Nominibus 4, 10.

62 See Dionysius Areopagita, De Divinis Nominibus 4, 14.

63 See Dionysius Areopagita, De Divinis Nominibus 4, 14. 
lishes the communion with the world not by means of essence, but that of His merciful outflowings ( $\pi \rho \circ o$ óor) that can be understood as equivalents to uncreated energies.

The consummation of Maximus' concept of movement is his theology of love. Maximus inherits and develops Dionysian idea of eros as ek-stasis and self-transcendence towards the Other (as we would say now). He expresses himself in an incredibly poetic and inspiring manner:

As intense longing (eros) and love (agape), the Divine is in motion, while as the longed for and beloved He moves toward Himself everything that is receptive of intense longing and love. [...] He moves others and is in motion in that $\mathrm{He}$ thirsts to be thirsted for, and longs intensely to be longed for, and loves to be loved ${ }^{64}$.

Maximus develops the Dionysian idea of God moving thanks to rational beings and their ability to relate. God exhorts the conscious created otherness to freely respond to His invitation to communion. The response makes us ek-static in the same manner as God is. It also transforms our natural faculty of desire and endows us with "spiritual ardor and fervent perpetual motion and sober madness" $" 65$ that reflect the existential experience of a true dialogue with God. This ek-stasis and self-overcoming is the essence of love, which is reflected in the invocation to love everyone equally deeply and dispassionately (in a non-objectifying, non-earthly manner ${ }^{66}$. On the opposite, self-love as solipsism and self-centeredness is a defective existence which does not only destroy unity with others, but also brings disorder into the natural

64 Maximus Confessor, Ambigua 10, PG 91, 1206C, tr. E. Theokritoff, N. Loudovikos, A Eucharistic Ontology: Maximus the Confessor's Eschatological Ontology of Being as Dialogical Reciprocity, tr. E. Theokritoff, Brookline 2010, p. 173.

${ }_{65}$ Maximus Confessor, Quaestiones ad Thalassium, PG 90, 548CD, tr. E. Theokritoff, p. 173.

66 See Maximus Confessor, De caritate 1, 10-15. 
faculties of human soul ${ }^{67}$. Only through love a human truly reflects the image of God and realizes his freedom.

Motion is directly tied to the faculty of will and free choice. Maximus associates natural ability of creation to move with the faculty of natural will ${ }^{68}$, and individual mobility with gnomic will. The latter is an individual way of self-determination that makes use of natural will ${ }^{69}$. In the works that preceded the Monothelete controversy, Maximus treated the concept of gnomic will positively, but while disputing with the Monotheletes on the nature of Christ's will, he gave the concept of gnomic will a negative (sin-related) connotation. This primarily happened because his opponents presented gnome as the only faculty of will that Christ possessed. According to the Monothelete interpretation, gnome was a function of intellect rather than a separate faculty ${ }^{70}$. This idea reinforced their claim that will belongs to hypostasis and not to nature. Maximus' negative in-

67 See Maximus Confessor, Ambigua 41. Cf. L. Thunberg, Microcosm and Mediator. The Theological Anthropology of Maximus the Confessor, Chicago 1995, p. 161; I. Hausherr, Philautie, de la tendresse pour soi à la charité selon Saint Maxime le Confesseur, Roma 1952, p. 57-63.

68 Cf. Maximus Confessor, Opuscula Theologica et Polemica 16, PG 91, 192B: „Natural will $[\ldots]$ is a faculty that strives to what is according to its nature. Every being, especially rational, strives according to nature what conforms to its nature, since it was by essence endowed by God with a capacity for this for its own development".

69 See Bathrellos, Person, Nature, and Will, p. 159.

70 Bathrellos notes that "the mainstream of Greek philosophy did not normally make

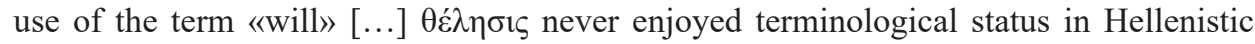
philosophy. [...] In classical antiquity volition was usually very closely related to mind, and there was hardly any room for a distinct volitional faculty" (Byzantine Christ, p. 121).

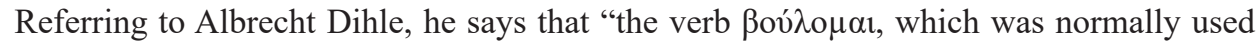
instead of the verb $\theta \dot{c} \lambda \omega$, always has - at least in classical and classicistic Greek-the connotation of planning which precedes the decision to act, and denotes, in its traditional use, deliberation plus decision rather than volition". Cf. A. Dihle, The Theory of Will in Classical Antiquity, Berkeley 1982. The concept of $\pi \rho 0 \alpha i \rho \varepsilon \sigma 1 \varsigma$, sometimes used synonymously to $\gamma \nu \omega ́ \mu \eta$, was understood as a combination of desire (ö $\rho \varepsilon \xi ı)$ ), deliberation and judgement. The term ö $\rho \varepsilon \xi 1 \varsigma$ had a connotation of irrational impulse and passion, and since the will was absent, human decision-making was understood as a conflict between ratio and passio. Maximus introduces the proper understanding of will as a separate faculty, since he was not content with the purely intellectualistic definition of will. 
terpretation of gnome has a polemical function but is not totally inconsistent with his understanding of the individual will. Sometimes gnomic will can be legitimately called sinful, if the individual process of deliberation and willing opposes the nature's proper movement, which is movement towards the good ${ }^{71}$. The concept of gnomic will shows that there is no individual end which could endure outside the communion with God. Each attempt in creating such is self-destroying.

An individual will is a faculty of decision-making and self-determination, which mark a human being as an individual hypostasis. Individuality and otherness is not a sign of sinful existence. The individual will, or particular will ( $\pi$ olò $\theta \varepsilon \dot{\lambda} \lambda \eta \sigma \varsigma)$, is tightly connected with the personal mode

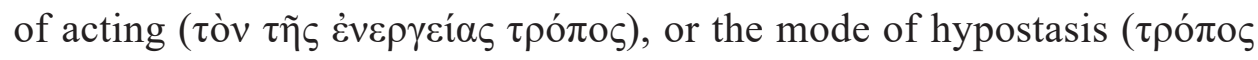

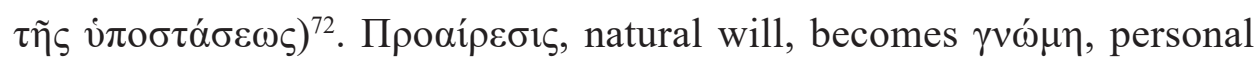
will, and is actualized through fixed state $(\ddot{\varepsilon} \xi 1 \varsigma)^{73}$. While gnomic will is a "mode of living", defining the general style of self-representation, fixed state is a "mode of functioning" that reflects the internal state influenced by the person's decisions. Gnomic will is directly responsible for decisions and the individual state that they cause ${ }^{74}$.

The term $\check{\varepsilon} \xi ı$ designates the individual activity, disposition and internal state of the hypostasis. This fixed state should be distinguished from the general position of nature $(\theta \varepsilon \dot{\varepsilon} \sigma \varsigma)$ and relation $(\sigma \chi \varepsilon \dot{\varepsilon} \sigma \varsigma)$ which is not necessarily stable ${ }^{75}$. The activity of the person ( $\left.\dot{\varepsilon} v \dot{\varepsilon} \rho \gamma \varepsilon 1 \alpha\right)$ belongs to the existential realm of human being. Although energeia as a faculty belongs to nature, it is always represented in the individual activity and self-representation of the subject. The tropos of hypostasis is a unique way in which he or she uses his or her natural faculties. This distinctiveness

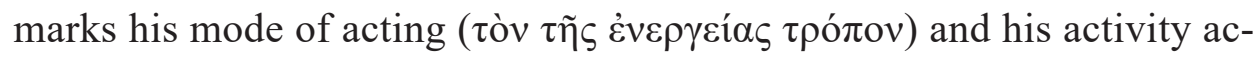

71 See Maximus Confessor, Opuscula Theologica et Polemica 16, PG 91, $193 \mathrm{~A}$.

72 See Maximus Confessor, Opuscula Theologica et Polemica 1, PG 91, $13 \mathrm{~B}$.

73 See Maximus Confessor, Opuscula Theologica et Polemica 1, PG 91, 17C.

74 See Maximus Confessor, Opuscula Theologica et Polemica 1, PG 91, 25A.

75 See Maximus Confessor, Ambigua 10. 


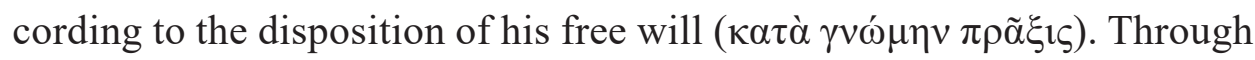
natural energies, a person is given to others and appears before them. According to the Cappadocians, it is through energeia that any being can be grasped, since the essence of beings is hidden from us ${ }^{76}$. The triads "being, well-being, eternal being" and "being, ill-being, eternal ill-being" reflect different " $\varepsilon \xi \varepsilon \varsigma \varsigma$ on man's way towards theosis or non-being. Nonbeing is an ontological state of total alienation from God as a source of goodness and life. Evil is, strictly speaking, the lack of the good, since it was not intended by God. Separating ourselves from God, we gradually lose participation in life, and our existence is only a weak resemblance of true life. In Maximus, to fall into this state is possible through sinful existence and deliberate rejection of God's love. If this state can lead to the complete loss of divine image, should be explored. Also, it must be figured out whether $\tilde{\varepsilon} \xi$ $\xi \varsigma$ can be externally induced, since the psychological and spiritual state of Muselmänner or Dokhodyagi is a reaction to an inhumane environment. Still, to our opinion, one should not totally reject the ethical approach to understanding this state. Numerous testimonies show that despite the atrocities of the camp life, some people managed to survive and retain their moral qualities. Victor Frankl passionately defends the ability of human free will to define one's existential state ${ }^{77}$. Although the cases are rare as compared to masses of people who lost hope, they quite convincingly demonstrate that human will can resist dehumanization. This does not mean that we should underestimate the horrors that led the prisoners to depersonalization and bitterness, but if human ability to take responsibility for their lives is undermined, there is a risk that a man becomes an object of external manipulations or natural determinations and not a subject.

76 See Gregorius Nazianzenus, Oratio Theologica 2, 5.

77 See V.E. Frankl, Man's Search for Meaning: The Classic Tribute to Hope from the Holocaust, Boston 1992, p. 74-75. 


\section{Virtue ethics and eschatology}

St. Maximus' anthropology is thoroughly eschatological. The image of God is not only the ontological ground of human person, but also the goal to which man should conform his existence. The image of God is present in the whole human being, not just the intellect (voṽ $)$ ) or reason $(\lambda o ́ \gamma o \varsigma)$. Theosis is the ultimate fulfilment of imago Dei, the moment when the distance ( $\delta i \alpha ́ \sigma \tau \eta \mu \alpha)$ between God and man disappears, and God comes to be "wholly present in the whole human being"78. The mutability and development of creation is natural to beings and indispensable from their ontological status ${ }^{79}$. Movement of beings leads to their constantly deepening relation with God and the overcoming of a creaturely state of being. Maximus envisions salvation and deification of creation as a continuous sacramental embodiment of $\mathrm{Christ}^{80}$. Deification is a possibility that is realized by individual beings in their striving towards communion with all creation and constantly strengthening connection with their logos.

Theosis per se is designated for beings endowed with hypostatic existence and free will. Movement, in St. Maximus' thought, is directly tied to man's existential choice regarding his relation to the uncreated, although non-personal beings also in a way participate in the divine life (otherwise they would not exist at all) ${ }^{81}$. Creation's participation in God is realized through man's fivefold mediation between the polarities of created order and between created and uncreated.

Theosis is an ontological state. As we have already mentioned, it is the state of nature itself and not something external that overcomes nature, as in case of St. Augustine's concept of grace. Rather, it is an appropriation by creature of ontological qualities of the uncreated. These

\footnotetext{
78 Maximus Confessor, Ambigua 7, tr. Constas, p. 87.

79 See Maximus Confessor, Ambigua 7, tr. Constas, p. 87.

80 See Maximus Confessor, Ambigua 7, tr. Constas, p. 87.

81 See Maximus Confessor, Ambigua 7, tr. Constas, p. 87.
} 
qualities, or God's attributes, become integral and irremovable qualities of human nature. Virtues are divine characteristics that penetrate and transform the whole human hypostasis. They are a type of $\varepsilon^{\xi} \xi \mathrm{i}$, not just an ethical attitude, although they result from prior free decision to eradicate sin from one's existence. Maximus understands the actualized virtue as a sign of one's deified state and not as a preliminary stage to contemplation, as would a straightforward interpretation of the threefold spiritual scheme suggest ${ }^{82}$. For him, ethics has direct consequences on ontology. As well as in case of theosis, man bears full responsibility for the movement towards "non-being", or evil-being. Man's existential decisions are a response to God's creative call to live. Human existence is a constant dialogue with the Creator: a man constitutes himself according to or in contrast to the mission that God has appointed to him. By our existential stance, we can either accept the gift of life-above-nature or reject the gift of life altogether. Mitralexis notes that for Maximus, hell is not a place of torture, but the state that follows from a person's inability to accept God's love ${ }^{83}$. Such person does not cease to exist literally, but his way of existence cannot be properly called life either. Therefore, theosis is the ultimate relationality and non-being is complete objectification. Both are not abstract definitions, but real ontological states that are reflected in person's individual qualities and activity.

\section{Conclusion}

In this article, we explored the concept of imago Dei in St. Maximus the Confessor's theology and its potential to answer burning anthropological questions that phenomena of Shoah and Gulag have generated,

82 See Maximus Confessor, Capita theologica et oeconomica 1, 20. Cf. F.D. Aquino, The Synthetic Unity of Virtue and Epistemic Goods in Maximus the Confessor, "Studies in Christian Ethics" 26/3 (2013) p. 383.

83 See Mitralexis, Ever-Moving Repose, p. 63. 
as well as the questions that humanity will be challenged with in the era of technology, or the "post-human" era. We have found that imago Dei is an irreducible and undestroyable aspect of human being and shaping his existence and defines his goal. According to Maximus, this goal is, ultimately, unity among the creatures, their communion around Christ the Logos, and communion of the whole creation with God. The presence of imago Dei in man is real: it is not simply a type of relations that shapes human life or an existential experience, or an ethical characteristic. All of the abovementioned follows from the fact that the image of God defines human beings as human and cannot be eradicated even in the situation of extreme dehumanization.

St. Maximus presents a balanced picture of created nature. Its mobility is a necessary mark of its ontological condition. At the same time, the motion of creation is not chaotic but arrives at communion with God. Creation therefore completes its self-determination and perfection in God. However, motion can become destructive for creation and cause mortality and decay, as in case of sin, which is a wrong movement towards non-being.

Maximus the Confessor's anthropology is a valuable source for modern reflection on human dignity. His concepts of virtue, stable state, the triads of "being, well-being, eternal being" and "being, evil-being, eternal evil-being" can serve as methodological instruments for postmodern and post-traumatic anthropology. To our opinion, the most important feature of Maximus' anthropology is the way in which relationality and freedom of human person is tightly connected with its ontological consequences. Therefore, the gap between ontology and ethics can be bridged. Still, to our opinion, there is an aspect of Maximus' theology that needs deeper study: his understanding of evil and radical evil and how the existence of evil can be reconciled with his hope for universal salvation of creation through man's mediation. The scope of this study did not allow us to fulfill this task, but proper acknowledgement of the problem of radical evil 
is necessary to make justice to all its victims. Of course, to adequately approach the problem of dehumanization, the study of St. Maximus is not enough. We should creatively interpret his teaching in light of the experience of Auschwitz and Gulag and take his holistic approach to anthropology as an inspiration for further reflection.

\section{Motion of Human Nature towards Imago Dei in the Thought of St. Maximus the Confessor}

(summary)

The traumatic experience of the $20^{\text {th }}$ century challenged humanity with the need for a radically new anthropology, free from objectification and exclusivism of various kinds. The phenomenon of dehumanization has become not only an ethical, but an ontological problem: is there any 'core' in man that remains unchanged despite all the sufferings that a man can experience. Modern systematic theology has not arrived to the solution of this problem, but St. Maximus the Confessor's profound understanding of the image of God in man as both ontological, dynamic, and eschatological, can help us build an anthropology that would have a firm ontological basis and would be deeply relational and therefore relevant for the postmodern context.

Keywords: motion; anthropology; dehumanization; imago Dei; Maximus the Confessor; deification; will

\section{Dążenie natury ludzkiej ku imago Dei w teologii św. Maksyma Wyznawcy}

(streszczenie)

Traumatyczne doświadczenia dwudziestego wieku ujawniły potrzebę nowej antropologii, uwolnionej od obiektywacji i ekskluzywizmu, które zdewaluowały wartość ludzkiego życia. Zjawisko dehumanizacji, ujawnione w obozach koncentracyjnych, stało się nie tylko problemem etycznym, lecz także ontologicznym, gdyż stawia pytanie o istnienie istoty człowieczeństwa w człowieku, której nie da się zniszczyć, bez względu na cierpienia, jakich doświadcza człowiek. Współczesna teologia systematyczna nie dotarła jeszcze do rozwiązania tego problemu. Święty Maksym Wyznawca proponuje jednak głębokie rozumienie obrazu Bożego w człowieku jako realności ontologicznej, dynamicznej i eschatologicznej.

Słowa kluczowe: ruch; antropologia; dehumanizacja; imago Dei; Maksym Wyznawca; przebóstwienie; wola 


\section{Bibliography}

Sources

Basilius Magnus, Epistula, PG 32, 325-340.

Dionysius Areopagita, De Divinis Nominibus, ed. G.M. Prokhorov, Dionisii Areopagit, Sochineniya, Maksim Ispovednik, Tolkovaniya, Saint-Petersburg 2002, p. 206-565.

Gregorius Nazianzenus, Orationes Theologicae, ed. U. Holovatch, Hryhorii Bohoslov, Pyat'sliv pro bohoslovya, Lviv 2018.

Leontius Byzantinus, Contra Nestorianos et Eutychianos, PG 86a, 1267-1398.

Maximus Confessor, Ambiguorum liber, ed. N. Constas, Maximus the Confessor, On Difficulties in the Church Fathers: The Ambigua, v. 1-2, Cambridge 2014.

Maximus Confessor, Capita de caritate, tr. G.C. Berthold, Maximus the Confessor, Selected Writings, New York - Mahwah 1985, p. 33-98.

Maximus Confessor, Capita theologica et oeconomica, PG 90, 1084-1176.

Maximus Confessor, Disputatio cum Pirrho, PG 91, 287-353.

Maximus Confessor, Epistolae, PG 91, 362-649.

Maximus Confessor, Opuscula theologica et polemica, PG 90, 9-286.

Maximus Confessor, Quaestiones ad Thalassium, tr. M. Constas, St. Maximos the Confessor, On Difficulties in Sacred Scripture: The Responses to Thalassios, Washington 2018 .

Plato, Symposium, ed. U. Holovatch et al., w: Platon, Benket, Lviv 2018.

\section{Literature}

Aquino F.D., The Synthetic Unity of Virtue and Epistemic Goods in Maximus the Confessor, "Studies in Christian Ethics" 26/3 (2013) p. 378-390.

Bathrellos D., Person, Nature, and Will in the Christology of Saint Maximus the Confessor, New York 2004.

Chrestou P., Maximus Confessor on the Infinity of Man, in: Maximus Confessor: Actes du Sumposium sur Maxime le Confesseur, Fribourg, 2-5 septembre, 1980, ed. F. Heinzer - C. von Schoenborn, Fribourg 1982, p. 261-271.

Dihle A., The Theory of Will in Classical Antiquity, Berkeley 1982. 
Frankl V.E., Man's Search for Meaning: The Classic Tribute to Hope from the Holocaust, Boston 1992.

Gavrilyuk P.L., Harnack's hellenized Christianity or Florovsky's Sacred Hellenism: Questioning two metanarratives of early Christian engagement with late Antique culture, "St Vladimir's Theological Quarterly" 54/3-4 (2010) p. 323-344.

Hausherr I., Philautie, de la tendresse pour soi à la charité selon Saint Maxime le Confesseur, Roma 1952.

Heidegger M., An Introduction to Metaphysics, tr. R. Manheim, New York 1961.

Kapriev G., Ipostas'i energii, in: Sovremennaya bolgarskaya patrologiya, Kyiv 2014, p. 113-136.

Kapriev G., The Conceptual Apparatus of Maximus the Confessor and Contemporary Anthropology, in: Maximus the Confessor as a European Philosopher, ed. S. Mitralexis et al., Eugene 2017, p. 166-192.

Larchet J.-C., Personne et nature: la Trinité, le Christ, l'homme: contributions aux dialogues interorthodoxe et interchrétien contemporains, Paris 2011.

Levi P., If This Is a Man, Paris - London 2014.

Levinas E., Totalité et infini, Nijhoff 1961.

Loudovikos N., A Eucharistic Ontology: Maximus the Confessor's Eschatological Ontology of Being as Dialogical Reciprocity, tr. E. Theokritoff, Brookline 2010.

Louth A., Maximus the Confessor, London 1996.

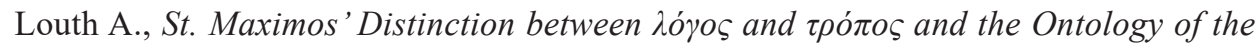
Person, in: Maximus the Confessor as a European Philosopher, ed. S. Mitralexis et al., Eugene 2017, p. 157-165.

Louth A., The Reception of Dionysius in the Byzantine World: Maximus to Palamas, "Modern Theology" 24/4 (2008) p. 585-599.

Manoussakis J.P., God after Metaphysics: A Theological Aesthetic, Indiana 2007.

Meyendorff J., Christ in eastern Christian thought, South Canan 1975.

Mitralexis S., Ever-Moving Repose: A Contemporary Reading of Maximus the Confessor's Theory of Time, Eugene 2017. 
Papanikolaou A., Learning How to Love: Saint Maximus on Virtue, in: Knowing the Purpose of Creation through the Resurrection: Proceedings of the Symposium on St. Maximus the Confessor, ed. M. Vasilievic, Belgrade 2012, p. 239-250.

Perl E.D., Methexis: Creation, incarnation, deification in Saint Maximus Confessor, PhD thesis, Yale University 1991.

Salés S.J., Papanikolaou A., 'A Power that Deifies the Human and Humanizes God': The Psychodynamics of Love and Hypostatic Deification According to Maximos the Confessor, "International Journal of Philosophy and Theology" 78/1-2 (2017) p. 23-38.

Skliris D., St. Maximus the Confessor's Dialectic of Logos, Mode and End in a Postmodern Context: Its Importance to a Theological Evaluation of Race and Nationalism, "The Journal of Eastern Christian Studies" 69/1-4 (2017) p. 249-280.

Thunberg L., Microcosm and Mediator. The Theological Anthropology of Maximus the Confessor, Chicago 1995.

Tolstaya K., Raschelovechivaniye kak kluch k realnomu ponimaniyu obraza Bozhyego, "Vestnik Svyato-Filaretovskogo instituta" 12/2 (2019) p. 103-139.

Yannaras C., Person and Eros, Brookline 2007.

Zizioulas J.D., Being as communion: Studies in Personhood and the Church, South Canan 1985.

Zizioulas J.D., Communion and Otherness, London 2009.

Zizioulas J.D., The Eucharistic Communion and the World, ed. L.B. Tallon, London 2011.

Zizioulas J.D., The One and the Many: Studies on God, Man, the Church, and the World Today, ed. G. Edwards, Alhambra 2010. 